\title{
The Development of Islamic Crowdfunding in Indonesia and Its Impact towards SMEs
}

\author{
Rifka Mustafida ${ }^{\mathrm{a}, *}$, Najim Nur Fauziah ${ }^{\mathrm{a}}$, Zahra Nabila Kurnia ${ }^{\mathrm{a}}$ \\ ${ }^{a}$ International Islamic University Malaysia, Malaysia
}

\begin{abstract}
Small and Medium Enterprises (SMEs) are taking a role as the backbone for sustained economic growth, particularly in developing countries. However, SMEs might not easily get financing from the banking institution due to the lack of financial history and collateral. Islamic crowdfunding has become a solution to deliver accessible financial services to unbanked SMEs in the countries, especially in Indonesia. Islamic crowdfunding impacts the SMEs regarding the ease of obtaining capital access, improving the welfare of SMEs, and creating growth for the national economy in the long-term. By using a literature review, this study aims to show how Islamic crowdfunding develops and how it affects SMEs in Indonesia. The result shows that Islamic crowdfunding potentially benefits SMEs in capital access, improving welfare, and economic growth.
\end{abstract}

Keywords: crowdfunding, Islamic crowdfunding, SMEs

\section{INTRODUCTION}

Indonesia has income per capita which continuously increases every year. The income of Indonesia per capita was USD 560 in 2000 and increased significantly in 2014 to USD 3.630. Moreover, Indonesia is the 10th largest economy in the world in terms of the ability of purchasing power (purchasing power), and it is considered as the largest Muslim majority country in the world with 207,176,162 Muslim people in Indonesia (BPS, 2010). Referring to that data, it indicates that the demand for products that comply with Sharia will continue to increase each year. Based on OJK data, in 2015 Islamic financial services sectors experienced positive growth. Islamic banking assets, Non-Banking Financial Industry (IKBN) and the nominal value of corporate sukuk outstanding increased where each grew by $8.78 \%, 11.13 \%$ and $39.19 \%$ respectively. It is seen that Islamic IKNB sector grew higher compared to Islamic banking sector (OJK, 2018a).

Small and Medium Enterprises (SMEs) become the backbone for sustained economic growth, particularly in developing countries. Globally, SMEs contribute to employment estimated at $43.5 \%$ and $57.8 \%$ and lead to creating new job opportunities. Unfortunately, SMEs in which have a low income might not easily get the financing from the banking institution due to

\footnotetext{
* Author in correspondence,

Email address: rifka.mustafida@rocketmail.com (Rifka Mustafida)
}

ISSN: 2549-3221 (Print) 2549-323X (Online)

DOI: $10.26487 /$ hebr.v4i3.2547 the lack of financial history and collateral (Ibrahim and Verliyantina, 2012). There are $49 \%$ of micro, small and medium businesses which do not have access to financial service. SMEs have a crucial role to contribute in Indonesian economy, however it seems to be difficult to obtain financing from banks. At the same time, investors are also looking for collateral before funding in high risk projects and it is very difficult to meet them because they are very limited in terms of capital (Andaleeb and Mishra, 2016).

On the other hand, fintech (Financial Technology) refers to a blend of technology and financial services, which changed the business model and reduced the barrier to entry. Fintech is composed of several types of transactions either payment, financing, as well as e-commerce. The development of fintech in Indonesia is currently quite high. Following this, in 2016 the transaction value of fintech in Indonesia is estimated at USD 14.5 billion USD, or $0.6 \%$ of the total value of the global transaction which is estimated at USD 2,355.9 billion (Bank Indonesia, 2016). Fintech industry in Indonesia keeps increasing from year to year. Indonesia experienced the best growth of fintech in 2015 until 2016 whereby fintech perpetrators increased for $78 \%$ from 2006. In November 2016, the perpetrators have reached 135-140 Fintech companies. From this data, 43\% of businesses are in the sectors of trade, $17 \%$ loan payments, 13\% Aggregators Crowdfunding, $8 \%$ Personal Finance Planning and $11 \%$ in other sectors. There are four types of crowdfunding operating in this world such as equity-based, asset-based, reward-based dan donation-based. (Islamic Development Bank, 2015).

Development of fintech in Indonesia is inseparable from the magnitude of the number of internet users. Currently, internet 
users in Indonesia exceed 100 million people even according to the APJII reached 132.7 million. Fintech has several advantages, one of which is to reduce costs and be more efficient fintech compared to the formal financial system. Implementation of the financing sector through fintech including crowdfunding and peer to peer lending and the current principles of financing in fintech is shareholding arrangements startup

Advancement of technologies fintech can be used by financial institutions to obtain funding more effective and efficient. The development of Fintech in Indonesia is currently very vigorous. The Global FinTech sector has attracted more than $\$ 111,8$ billion in investment (KPMG, 2019). Following that more than $73 \%$ of the world's unbanked and $22.2 \%$ are Muslim countries, Fintech has potential to promote financial inclusion through catering to the standard of living for people. Islamic finance in particular offers solutions to micro, small, medium enterprises, decreasing the gap between financial institutions and those that seek project financing (IFBS, 2017).

Indonesia is the largest Muslim country in the world. According to BPS, (2010) of Muslims in Indonesia in 2010 accounted for $207,176,162$ people. It also indicates that the demand for products that comply with Sharia will continue to increase each year. Whereby only $36 \%$ of the population having bank accounts (Demirguc-Kunt et al., 2018). Islamic crowdfunding especially equity based holds the promise of delivering accessible financial services to the unbanked SMEs in the country. Therefore, this study aims to show how Islamic crowdfunding develops and how it affects SMEs in Indonesia.

\section{LITERATURE REVIEW}

\subsection{Fintech and Crowdfunding Definition}

Fintech is a product or service-based technology provided by financial institutions. Fintech often produces innovative and main services. Fintech is composed of the words Financial and Technology, namely financial services through technology. Fintech is a system that presents an innovative business model and technology that can improve financial services. Not only in the definition of fintech limited startup companies (new player) but also companies that have long become a provider of financial services companies that are not even financial services providers, such as companies and telecommunications service providers. Fintech is composed of several types of payment sector, namely, personal assistant, clearing, and settlement. Fintech is currently using multiple platforms, such as mobile phone applications and websites.

As mentioned by Estellés-Arolas and de Guevara (2012), crowdfunding is a type of fundraiser sourced from many investors through a participatory online-based platform intended to finance the registered businesses in the platform. Such cooperation may take the form of participation, fundraising, and knowledge or expertise. The current practice of crowdfunding is the impact of commercialization of the modern-day Internet. The use of these technologies is lowered transaction costs, effective and efficient (Agrawal et al., 2014).

The application of the crowdfunding concept is fundraising from small to moderate contributions from many people to fund a project or small and medium-size business (Alonso, 2020). From the above definition then it can be inferred that crowdfunding is the use of the amount of money a little by the people or organizations for funding a project, individual businesses, or other financing needs through an online-based platform a website, or application. There are three parties in crowdfunding platforms i.e. project initiator, funder, and platform provider. Islamic Crowdfunding is divided into four categories: donationbased, reward-based, asset-based, and equity-based crowdfunding.

\subsubsection{Islamic Donation-Based Crowdfunding}

Islamic Donation-Based Crowdfunding is a scheme where the funder donates funds to the project initiator (SMMEs) used for his business without any compensation. In this scheme, according to (Jenik et al., 2017) party provides the funding for an activity or project aimed at philanthropy without expecting compensation.

\subsubsection{Islamic Reward-Based Crowdfunding}

According to Jenik et al. (2017) in this scheme, the funder gives funds to the project initiator through crowdfunding platform providers. Furthermore, the funder received appreciation for financial support or services rendered in the form of a product or service developed by the project initiator (MSMEs). The rewards take the form of pre-purchasing of products or services or a token of appreciation, such as a thank-you note (Kuppuswamy and Bayus, 2018). A reward-Based Crowdfunding scheme is a good strategy for the MSMEs to market their products or services. The scheme is a focus on social responsibility and social development (Alonso, 2020).

\subsubsection{Islamic Equity-Based Crowdfunding}

This scheme is a scheme of equity capital where the funder provides funds to owners of MSMEs (project initiator) for use in running his business. The investor receives a return as compensation from funds invested for MSMEs. This scheme represents the essential expectations in Islamic finance i.e. by combining social and interest benefits of investments through profit and loss sharing (Islamic Development Bank, 2015).

\subsubsection{Islamic Asset-Based Crowdfunding}

This scheme gives the funder funds/assets to platform providers for next bought the asset will be used by MSMEs to run his business. In this scheme, the MSMEs can also buy or rent these assets. The scheme is most widely applied by Islamic banks, due to the minimal risk. The contract that can be used in this scheme is Murabaha and Ijara.

\subsection{Small Medium Enterprises in Indonesia}

SMEs are a solution to the problems of a developing country that has a significantly increasing population growth rate compared to the growth of jobs. A micro business is one form of business that has a large role with its ability to create extensive employment opportunities can provide economic services broadly to the community, play a role in the process of equity 
and increase people's incomes, encourage economic growth, and maintain the stability of the country's economy.

Small-medium enterprises have an important role in pushing the economy of Indonesia, which is evidenced by the absorption of labor to reach 107.6 million or $97.16 \%$ of the total workforce in Indonesia which totaled 110.8 million up to the year 2012. Small-medium enterprises also proved able to survive during the economic crisis years 1997-1998, as evidenced by the rise in the number of small-medium enterprises reached approximately 56.5 million or $99.9 \%$ of the total number of Group business in Indonesia. The growing number of smallmedium enterprises in Indonesia gives an effect to increase the contribution of small-medium enterprises in Indonesia's economy. Small-medium enterprises sector currently contributed amounted to $60.3 \%$ to GDP, amounting to $5.18 \%$ and contribute towards economic growth in the quarter II 2016. Although SMEC Indonesia experienced rapid growth, small-medium enterprises still have major constraints to capital or funding (Retno Wat and Winarno, 2018).

As many as 48 percent of SMEs in Indonesia have not been served well and the potential for funding through crowdfunding has reached 27.5 million US dollars. The Ministry of Cooperatives and SMEs (2016) recorded 2,253 units of Savings and Credit Cooperatives and 1.4 million members.

Furthermore, even invests through equity crowdfunding based risk, since there is no secondary market for shares and the valuation of companies that develop, however, equity-based crowdfunding can become a welcome link to stakeholders, such as shareholders, suppliers, and customer so that the interaction between the company's stakeholders easier to support their local businesses (Retno Wati and Winarno, 2018).

\subsection{Historical Development of Crowdfunding and SMEs in In- donesia}

There are 56.6 million or $99 \%$ of total business unit SMEs in 2015 and contributed 22\% to PDB (UMKM Indonesia, 2016). Difficult banking procedures become a reason for SMEs to approach banks (Financial Institutions Group, 2016). Related to this, $49 \%$ of them don't have access to banks and choose to borrow from informal institutions. In 2017 Indonesian government issued Kredit Usaha Rakyat to accommodate SMEs' financing needs with an easier process. In August 2018 SMEs financing reached 1,024 trillion rupiahs, but the portion of sharia banking is still low. In early 2019, Islamic banks only distributed 0,6\% of the total KUR to 22.850 SME customers (Omar, 2020).

On the other hand, peer-to-peer lending and crowdfunding have gotten popular since 2015. After growing fast, Bank Indonesia took the first rule to accommodate fintech industry needs in 2016. In 2017 Indonesia's FinTech Association was established with twenty members. At the beginning of their appearance, fintech had not been regulated by the government.

In Indonesia, the development and regulation of Islamic Crowdfunding are supervised by three institutions such as the Bank of Indonesia, the Indonesian's Services Authority (OJK), and the National Islamic Board. Different from OJK, BI sets the monetary and payment system (macro-level) while OJK regulates the financial institutions (micro-level).
The first regulation of fintech is issued by the Bank of Indonesia (BI) in 2017. In this Regulatory, Bank of Indonesia wants to guarantee financial technology ecosystems are supporting the creation of monetary stability, financial system stability, and payment systems that are efficient, smooth, safe, and reliable to support sustainable and inclusive national economic growth. It also regulates sandbox design to assess the business model and risk profile of fintech companies generally. Moreover, in 2018, Indonesian Services Authority (OJK) issued equity crowdfunding regulatory POJK.04/2018 to provide certainty for businesses and the customers. This regulation covers the arrangement of equity crowdfunding platforms, Equity crowdfunding services, and investors.

All crowdfunding platforms operating in Indonesia have to register as a company or cooperation, and report their operational things semiannually, yearly, and incidentally to OJK. The platforms also have a minimum capital amounting to 2,5 billion rupiahs and can offer the project to investors for sixty days each project. For security systems, OJK requires platforms to provide safe security in protecting from hacking. Moreover, OJK also designed a regulatory sandbox for qualified firms (members of the Indonesian Fintech Association) attempting to implement a new business model and assess its risk (OJK, 2018a).

In 2018, the National Islamic Board (DSN-MUI) issued a fatwa about Islamic fintech "Financing Services Based on Information Technology Based on Sharia Principles". In this fatwa, National Islamic Board emphasizes the platforms may not conflict with Sharia principles, like usury, gharar, maysir, tadlis, dharar, zhulm, and haram. This fatwa covers fintech firms operating financing services and payment gate systems (Dewan Syariah Nasional, 2018).

To develop the fintech sector, OJK officially launched OJK Innovation Center for Digital Financial Technology (OJK Infinity) at OJK's headquarters. It is designed to be the place where stakeholders, regulators, government, and academics can cooperate and discuss ways to improve the development of Indonesia's fintech industry, while at the same time strengthening consumer protection.

Islamic crowdfunding platforms have grown rapidly to cater to SMEs in various sectors such as investree in the retail sector, iGrow in the agricultural sector, Ethiscrowd in the housing and property sector, etc.

In February 2019, there are 96 conventional and 3 shariah fintech platforms listed by OJK. Several Islamic Crowdfunding platforms such as Kapitalboost, and Ethiscrowd. Kapitalboost and Ethiscrowd are based in Singapore but they are investing in Indonesian projects. In 2018 transaction crowdfunding is at 2,34 billion rupiahs. Crowdfunding has a $31 \%$ market share in the fintech sector (Katadata.com, 2020). Islamic crowdfunding platforms listed by OJK have distributed 77 billion rupiahs in 2018, while the potency of Islamic crowdfunding reaches 5-7 trillion transactions per year. The transaction of crowdfunding has grown $16,3 \%$ per year. 


\subsection{The Development Current Status of Islamic Crowdfunding Platforms}

Crowdfunding financing, nowadays, gets more Scholar's concern, especially on Islamic crowdfunding. This is mainly because very suitable to be implemented due to its easiness for project initiators, not bankable customer and starters business. An interesting phenomenon that has been explored only recently is Islamic crowdfunding that can be positioned in the more general realm of Islamic finance. Islamic finance is perceived as value-oriented, where it should meet maqashid (purposes or goals) of sharia. Islamic finance and crowdfunding both conceptualize costumer as investors and might potentially provide investment opportunities with higher returns. In addition, it emphasizes transparency, mutual involvement, and trust. Sharia and crowd-funding have a similar goal and philosophical foundation, which are aimed to build communities, encourage risk-sharing, democratize wealth, and channel capital to real economic activity.

Furthermore, there are some basic features distinguishing Islamic crowd-funding from conventional one, which relates to: (1) investing only in halal projects, (2) the absence of interest rate, prohibition of gambling and speculation (riba, maysir, and gharar), (3) existence of sharia supervisory boards(Achsien Purnamasari, 2016). Islamic crowdfunding is very suitable when applied to a country with a majority of the Muslim population. The appropriate form of Islamic crowdfunding is: Musharaka and Qardh. Musharaka Islamic crowdfunding is intended as an investment, donation, and equality-based goal. While Islamic crowdfunding Qardh is intended to support project financing on a loan basis. (Wahjono et al., 2015).

\section{METHODOLOGY}

This study used a literature review as the method in completing the research. In collecting data, the authors used the library research method, a step-by-step process in acquiring and analyzing the existing data from various relevant sources regarding Islamic crowdfunding in Indonesia and how it affects SMEs. Data acquired from the official website of several Islamic crowdfunding companies were then analyzed in order to perceive how every company supports SMEs in Indonesia.

\section{DISCUSSION}

The growth prospect for Islamic crowdfunding is huge considering the relatively small market and massive demand for SME financing. According to Kapitalboost.com estimation, that the total Islamic crowdfunding was USD30 million in 2015 versus the total crowdfunding market of USD 25 billion. SMEs are the backbone of the ASEAN countries. However, globalization, advances in technologies and communications, trade liberalization, and the evolution of the production processes pose challenges that need to be better addressed as ASEAN continues to deepen its economic integration.

According to a joint report conducted by the International Finance Corporation and McKinsey Company, Two Trillion and Counting: Assessing the Credit Gap for Micro, Small, and Medium-Size Enterprises (2010), the difficulties that SMEs face in obtaining credit in the developing world have resulted in a large funding gap of approximately USD \$1.2 trillion in South East Asia (Chironga et al., 2012).

With a 261.12 million population, only $48.9 \%$ of Indonesians are banked. Only 143.2 million people have the access to the internet and 130 million of them are active social media users. Fintech Indonesia Players Overview are: Payment $38 \%$, Lending 31\%, Personal Finance Wealth Management $8 \%$, Comparison $7 \%$, Insurtech $6 \%$, Crowdfunding $4 \%$, POS System 3\%, Cryptocurrency \& Blockchain 2\%, and Accounting $1 \%$. The total value disclosed Fintech investment in 2017 was USD $\$ 176.75 \mathrm{M}$, with a transaction value in the Fintech market up to UDS \$22,3 Million and expected to grow 16,3\% annually.

Economic growth in Indonesia has averaged about $6 \%$ for the last five years. The growth of the Islamic finance industry has been outpacing the growth of conventional financing for over the last 10 years. With the unbanked accounting for more than half of the population, the potential for growth is still immense. The sector is expected to continue its growth at a double-digit level for the next five years.

The growth of Indonesia's SMEs is growing by $2 \%$ every year. According to Badan Pusat Statistik (BPS), currently Indonesia has 62 million units of SME and is projected to grow by $3 \%$ in the next coming years (bps.go.id). The growth of Indonesia SMEs is supported by the government by providing training and financial access. The ASEAN Coordinating Committee on Micro, Small and Medium Enterprises (ACCMSME) also has set out goals in the ten-year ASEAN Strategic Action Plan for SME Development 2016-2025 (SAP SMED 2025) under the post-2015 ASEAN Vision: (1) promote technology, productivity, and innovation; (2) increase access to finance; (3) enhance market access and internationalization; (3) enhance the policy and regulatory environment; and (4) promote entrepreneurship and human capital development.

\subsection{Market and Competitive Analysis of Crowdfunding in In- donesia}

There are 99 financial technology companies registered in Indonesia Financial Service Authority (OJK). Among those only several companies that operate with a crowdfunding business model and only a few that operates with a shariah-compliant basis, namely Ammana, Danasyariah and Investree.

Generally, there are four forms of crowdfunding; rewardsbased crowdfunding, donation-based crowdfunding, equity crowdfunding, and debt crowdfunding. Lending via crowdfunding has been the fastest growing mode of lending with the total crowdfunding market of 22.2\% in 2012 rising to $68.3 \%$ in 2014 globally (Massolutions, 2015). Shariah accepts the first three types of crowdfunding (reward, donation, and equity-based). However, conventional debt crowdfunding is not permissible in Islamic because it is based on interest (ribā).

Crowdfunding players in Indonesia can be divided into three subsectors as Equity Crowdfunding, Donation Crowdfunding, 
and Debt Crowdfunding. Debt and Equity Crowdfunding has found their way to penetrate the market because the government showed some interest in fintech. Meanwhile, the different situation is shown by the Donation Crowdfunding subsector that seems barely fit in the market.

In contrast to equity and debt based which tends to commercial, Donation, and reward-based crowdfunding considered as social entrepreneurship. Most people give their money as charity.

In order to compete in the crowdfunding market, Islamic crowdfunding companies must increase the awareness of Muslims to understand the difference between conventional and Islamic crowdfunding. However, Islamic crowdfunding gives more benefit to both ventures and investors, because they are interestfree based.

Another factor that may also boost the growth of the sector is the increased introduction of Islamic finance structures to meet the specific needs of SMEs and to limit the risks to investors. However, to compete in the fintech industry, the crowdfunding company must be successful in campaigning their project as well as increase the awareness of the potential ventures and investors.

Kickstarter, one of the crowdfunding platforms in Europe found that the success rate of campaigns with updates is as high as $58.7 \%$ compared to those without updates at $32.6 \%$. Therefore, the Islamic Crowdfunding platform should boost their campaign to increase the awareness of ventures and attract an investor to succeed in their projects.

In February 2019, the loan on crowdfunding has grown rapidly more than $655 \%$ with a total value of IDR 28.36 Trillion (USD 2.04 Million). The total borrower account was 4.36 million accounts and 208,000 investor accounts. According to Financial Service Authority (OJK), 6.35\% of the total borrowing (IDR 1.8 Trillion) is problematic. $3.17 \%$ of loans have not made payments for 30-90 days, and $3.18 \%$ defaulted (no payment for more than 90 days). Nevertheless, $93.65 \%$ was successful in making the payment on time.

\subsection{How the Development of Islamic Crowdfunding May Af- fect the SMEs in Indonesia}

Crowdfunding has the potential to play several important roles in the developing world's entrepreneurial and venture finance ecosystem. Crowdfunding is perceived to contribute to economic growth through the creation of new and increasing flows of credit to SMEs and other users in the real economy (Achsien and Purnamasari, 2016b).

In addition, Crowdfunding also brings the effect of positive externalities, which encourages the public's desire for entrepreneurship, due to the convenience provided to get funding. The crowdfunding scheme is also able to stimulate people's creativity to create products that are unique, creative, and have selling power. crowdfunding, which is usually already internetbased, will facilitate people's access to investment so that it can stimulate the birth of new investors (Akbar, 2016).

Furthermore, we classified the Islamic crowdfunding impact towards the SMEs as below:

\subsubsection{Capital Access}

Crowdfunding could be alternative financing for SMEs to develop their business. The low borrowing credibility, risk of default, no collateral, might be obstacles for SMEs to obtain capital financing from the bank. Thereby crowdfunding financing will be an opportunity for SMEs to enhance their capital business. Whereby crowdfunding financing has lower costs than loans at banks. In addition, Crowdfunding also provides higher returns on deposits in banks, as well as higher risks (Akbar, 2016).

\subsubsection{Improving the Welfare of SMEs}

According to Bank Indonesia and the LPPI (2015), the MSME sector has a proportion of $99.99 \%$ of the total business players in Indonesia or as much as 56.54 million units. Increasing the capital of MSMEs through crowdfunding platforms will increase business value so that significant numbers of MSME entrepreneurs have the opportunity to be more prosperous (Noor, 2017).

\subsubsection{Economic Growth}

According to the World Economic Forum (2015), the distributed fund for SMEs creates growth for the Economy. SMEs have the capital to develop and this will result in increased goods and services produced and create jobs. Thereby the application of platform-based Crowdfunding by LKMS will have a domino effect on the welfare of business units (SMEs). Islamic Crowdfunding also brings the effect of positive externalities, which encourages the public's desire for entrepreneurship, due to the convenience provided to get funding (Akbar, 2016).

Islamic financial institutions play important roles in developing the SME economy, especially in rural areas. According to the Ministry of Cooperatives and SMEs (2016) noted the number of members of the Savings and Loan Cooperative reached 1.4 million people or Business, Small, and Medium Enterprises. According to Bank Indonesia and the LPPI (2015), MSMEs have a proportion of $99.99 \%$ of the total business actors in Indonesia or around 56.54 million units. In addition, the MSME business contributed around $60 \%$ of GDP. According to the World Economic Forum (2015), if funds from the public can be invested in the MSME sector, it can create growth for the economy. MSMEs will have the capital to develop and this will result in increased goods and services produced and create jobs. It can be concluded that the application of platformbased Crowdfunding by LKMS will have a domino effect on the welfare of business units (MSMEs) and in the long run, will increase national economic growth.

\subsection{Islamic Crowdfunding and Its Impact in Indonesia}

In 2016, there are only 67 fintech companies in Indonesia that have been registered and licensed in the OJK regulation No. 77 of 2016 which consists of 65 conventional companies and 2 sharia companies. Meanwhile, 40 fintech companies are in the registration process, 57 registration applications are returned, and 38 companies are interested in registering, so the total potential of fintech in Indonesia is 202 companies (OJK, 2018b). 
Table 1: Differences between Conventional and Islamic Crowdfunding Based on Type

\begin{tabular}{lll}
\hline Type & Conventional Crowdfunding & Islamic Crowdfunding \\
\hline $\begin{array}{l}\text { Reward based } \\
\text { Donation Based }\end{array}$ & $\begin{array}{l}\text { Materialism } \\
\text { Humanitarianism }\end{array}$ & $\begin{array}{l}\text { Materialis, it may also include the element of al-Falah } \\
\text { Based on religious belief such as Waqf, Zakah, Sadaqah, etc. } \\
\text { the ultimate objective is al-Falah }\end{array}$ \\
& $\begin{array}{l}\text { Angel Investors, Venture capital- } \\
\text { ists }\end{array}$ & $\begin{array}{l}\text { Based on Mudharabah, and Musharakah. The Musharakah } \\
\text { based may similar to equity-based crowdfunding. However, } \\
\text { Mudharabah based crowdfunding is that the crowd provides } \\
\text { the entire capital and the ccompany is responsible for the busi- } \\
\text { ness operations. In the case of profit, the crowd and company } \\
\text { share the profit based on pre-determined ratio. However, in } \\
\text { the case of loss, the crowd is responsible for all losses } \\
\text { Sale based contracts- Murabahah, Tawarruq, and Ijarah }\end{array}$ \\
\hline \multirow{2}{*}{ Debt Based } & $\begin{array}{l}\text { Lending based on interest; also } \\
\text { called P2P crowdfunding }\end{array}$ & \\
\hline
\end{tabular}

However, nowadays there are 99 companies licensed and registered in OJK, whereby three companies are Islamic crowdfunding (OJK, 2019). There are several crowdfunding companies which offer shariah financing scheme that significantly impacts the society in Indonesia, i.e. Investree, Kapitalboost, and Ethiscrowd.

\subsubsection{Investree}

Investree, historically, is a financial technology company in Indonesia as an online marketplace that brings together people with deficit money with people with surplus money. Then, not only to generate high profit from the lender but also to make the financing more affordable and accessible for borrowers. Moreover, Investree develops financial services in Indonesia more intelligently. By connecting lenders who want to help provide loans and borrowers who want to get loans online, Investree makes lending and borrowing activities more accessible to both. Investree gives attractive returns for lenders and competitive interest loans for borrowers. Furthermore, Investree instills and strengthens work principles based on the values of integrity, innovation, and professionalism to benefit stakeholders under the banner of sharing economy - a socio-economic system that makes personal resources an opportunity to share. Finally by providing and applying for loans through Investree can help each other achieve financial goals while simultaneously empowering the economy of the Indonesian people ("Investree Indonesia's Peer-to-Peer Lending Marketplace,” n.d.).

It is interesting to note that, Investree offers Syariah financing on their platform. They make a benefit to both sides of the lender and borrower. From the lender perspective, they emphasize that all financing activities are without usury and free from transactions that are prohibited by Islamic law. Also, the lenders will immediately receive return income in the form of ujrah wakalah as a collection service paid by the borrower without any cost. On the borrower side, not only free from usury and free of interest for the customer but this financing product disclosure regarding the costs, also any person can access the financing at any time. ("Investree - Indonesia's Peer-to-Peer Lending Marketplace," n.d.)
Based on the Investree disclosure report, currently, April 2019, Investree has been reached at almost IDR. 2.36 Trillion of the Total value of Loan facilitated, IDR 1.75 Trillion of the value of loan disbursed, IDR 1.42 Trillion of value Loan paid. Also 4250 Total of Loan Disbursed, 3238 Total of the loan paid and 10 Total loans to Fund. Whereby, there are $16.4 \%$ average rate of return, 3 days average time loan funded and non-DPD 90 loan Quality or similar with $99.42 \%$. Besides, the Investree platform, nowadays, puts current funding opportunities to see the list of loans and opportunities to fund the money. They put and distinguish the shariah industry or company which need fund with another conventional area by giving "shariah" label.

\subsubsection{Kapital Boost}

Kapital Boost is created to help small businesses grow big or protecting the social welfare of less-privileged communities. Kapital boost is a hybrid crowdfunding platform located in Singapore. Also, this platform allows its members to invest or donate in a way that is ethical and Sharia-focused.

Generally, Kapitalboost offers SME, Private, and Donation crowdfunding. SME crowdfunding offers small businesses shortterm financing alternatives with a fast and friendly approval process and at competitive rates. This financing uses Murabahah (Cost plus Profit) contract, whereby SMEs can raise financing for asset purchases. They may also raise financing through the Qard and Wakalah structure, or invoice financing, to seek cash advance on unpaid invoices to meet immediate working capital needs. Also, private crowdfunding offers only to those who are not eligible for crowdfunding based on their minimum requirements. This could be a golden opportunity to raise financing by targeting their group of Investors and professionally market their funding needs to their network of friends and families.

Kapital Boost offers SMEs a clear and legal financing structure and contracts to reduce uncertainties and potential conflicts between the SME and investors. Also, Kapital Boost offers members the opportunity to invest in the Akhirah (hereafter). The Donation Crowdfunding platform allows members to support non-profit, social-based projects in less-privileged communities within the region. While financial returns are not ex- 


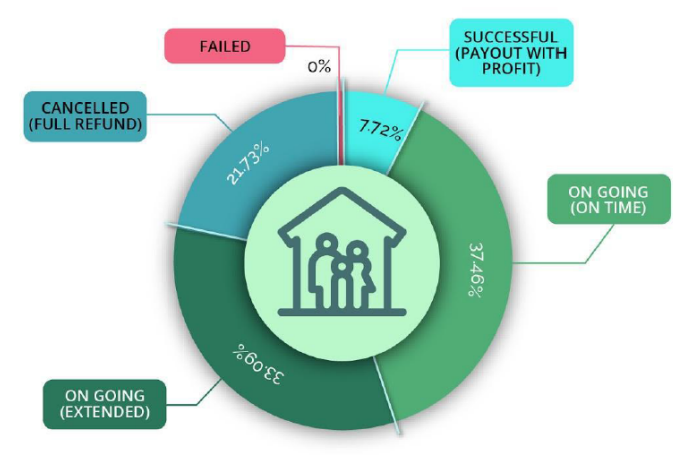

Figure 1: Performance of Indonesian Affordable Housing Campaigns

pected, the reward for helping those in need will be multi-fold in the hereafter. Improving social welfare is also a means of accelerating community growth in the future. There are several SMEs in Indonesia financed by Kapital Boost.

\subsubsection{EthisCrowd}

Ethis Crowd is the world's first Real Estate Islamic Crowdfunding Platform and one of the first investment Islamic Crowdfunding platforms in the world. Ethis is an early leader in Islamic Crowdfunding. They operate in 3 countries: Singapore, Indonesia, and Malaysia. They are also at the same time setting up and processing regulatory approvals in 2 other countries. Ethis is one of few platforms globally that have actively implemented Islamic Finance models and structures for CF. They invest directly in real estate development and construction projects, focused on social housing in Indonesia. We have also on two occasions run campaigns investing in construction and infrastructure.

Ethis Crowd uses risk-sharing financing in the form of $\mathrm{Mu}-$ darabah (non-equity) profit-sharing, where investors and project owners take up performance and default risk together and share project profits. They also use Murabaha, which is a direct sale and purchase of real estate assets or construction materials.

Ethis crowd started recently an advanced variation of Murabahah which is the Istisna' + Murabahah model. Technically the crowd orders house and assets from the developer and make progressive payments to contractors as these houses are built before selling them to Islamic Banks at a profit. Most Ethiscrowd projects are affordable housing campaigns.

Note:

- Successful: Completed with capital and profits paid out successfully to crowd investors

- On Going: Still under construction or development

- Cancelled: Funds raised but not disbursed to project when pre-agreed criteria or milestones were not fulfilled. All investors' capital has been returned in full.

- Failed: Some or all investor's capital may be lost
From this depicted picture, it is clearly seen that the number of still under construction or development on time and extended were the highest percentages at 37.4 and $33.09 \%$ respectively. Following these, all investors' capital has been returned in full at approximately $21.73 \%$ and completed with capital, and profits paid out successfully reached only $7.72 \%$. It is interesting to note that, there were no failed transactions and no investor's capital may be lost.

\subsection{Issues and Future Development of Islamic Crowdfunding towards SMEs}

\subsubsection{Issues}

- Trust

Trust plays an important role in many social and economic interactions such as crowdfunding that involve uncertainty and dependency (Kang, Gao, Wang, Zheng, 2016). It is because the parties in every financial transaction need security, especially for the funders who entrust their fund to the fundraiser. Trust management as one of the efforts in preserving funders' loyalty significantly promoted fundraising performance (Zheng et al., 2016).

There are still many people who still do not have enough trust to do e-commerce or any financial transaction on the internet (Achsien and Purnamasari, 2016a). Even for those who are comfortable with online transactions, trusting a total stranger with executing a project is another problem compounding the issue. This may therefore be a disadvantage to crowdfunding investors who are at a distance and unable to develop the face-to-face relationships that respondents feel are a key factor in building this style of strong relationship.

Interestingly, Bock et al. (2014) state that crowdfunding is inherently psychological and social and that social dynamics in the online ecosystem create fundinginfluencing variables for a capital exchange through the crowd. The social dynamics in crowdfunding are constructed around the relationships in heterogeneous social networks. Therefore, there may be a discontinuity between the concept of "relationship" between bankers and the more emotionally driven intuition and intelligence of the crowd (Durkin et al., 2016).

- Quality of projects presentation and campaign

To attract potential investors, both project owners and fundraisers have to display attractive project presentations. This has to be noticed while paying attention to the contents to prevent any information asymmetry between investors, fundraisers, and project owners. Currently, the SME project presentation is still poor and needs to be improved. Mostly the current presentation only consists of common documentation and few sentences to explain the projects. Some of the Islamic crowdfunding platforms such as Ammana Fintek Syariah has provided prospectus for better marketing, but unfortunately, it is only applied to more than 500 million Rupiah financing. 
Table 2: 2 KapitalBoost Financial Projects for SMEs in Indonesia

\begin{tabular}{llc}
\hline SMEs Industry & Purpose of Financing & Amount of Financing \\
\hline \hline Claro Kreasi Abadi & Financing of Invoice for Cleaning service & $\mathrm{S} \$ 275,000$ \\
Kokoh Mizantium Indonesia & Purchase of Materials for Office renovation & $\mathrm{S} \$ 83,300$ \\
Griya Daya Hijup & Purchase of fabric and womenwear & $\mathrm{S} \$ 38,300$ \\
Asahi Esda Electric & Purchase of Materials to build switchgears & $\mathrm{S} \$ 183,000$ \\
Bintang Trans Khatulistiwa & Financing of Invoice for fiber optic connection & $\mathrm{S} \$ 72,200$ \\
Risqi Amanah madani & Purchase of LPG gas refill & $\mathrm{S} \$ 48,300$ \\
Adhi Mitra Teknik Utama & Financing of Invoice for fibre optic installation & $\mathrm{S} \$ 50,400$ \\
Panca Agri Solusindo & Financing of Invoice for agricultural advisory & $\mathrm{S} \$ 40,100$ \\
Tri Daya Berdikari & Purchase of materials & $\mathrm{S} \$ 73,000$ \\
Graha cipta Anugrah Persada & Financing of Invoice for corporate video making & $\mathrm{S} \$ 30,000$ \\
\hline
\end{tabular}

Besides the presentation, the fundraisers are also lack marketing ability in regard to campaigning the SMEs projects. Nowadays social media such as Facebook, Twitter, and Instagram has become the main media for sharing information globally. Moreover, some websites and E-commerce platforms have provided some spaces for advertisement matters. Thus, the fundraisers must utilize those opportunities to share their project information, even to advertise their companies. Since basically, Islamic crowdfunding could service SMEs better than banks, these platforms are expected to give maximum effort in gaining capital and the best services to the SMEs.

\section{- Limited contract types}

Currently, most Islamic crowdfunding platforms utilize Murabahah and Wakalah bil Ujrah, as their operating contracts. In Murabahah contract, the investors will get their principal plus the "markup" because the asset is sold to the SME at an additional price from whatever was paid to the supplier. Meanwhile, in Investree case, it is more reliant on Wakalah bil Ujrah contract. The main product, Invoice Financing, works by guaranteeing invoices; a bill for the goods or services provided by Payor to obtain financing from the Lender. At the end of the financing period, Payor will pay for the invoice and the Lender receives funding principal and Ujrah as the income for billing documents management services. These Islamic contracts have successfully encouraged shariaconcerned investors to embed their fund in these platforms, and SMEs players to ask for financing.

Despite all the growth and achievement, Islamic finance yet maximizes its full potential. Wahbah Al-Zuhayli stated in his book, Al-Fiqh Al-Islami wa-Adillatuh, that Islamic banks must be sensitive to the needs of the society since its primary aim is not for gaining profit but rather to endorse social goals of socio-economic development and alleviate poverty (Yusof et al., 2009). This could be achieved if Islamic finance put more reliance on equity rather than debt financing.

- Possibilities of money laundering and terrorism funding
Besides all the benefits, crowdfunding can also be abused by some individuals for crime, for instance, money laundering and terrorism funding. Money laundering in crowdfunding may occur when an issuer colludes with investors to exchange money for securities in a nefarious enterprise under the facade of a business transaction. Moreover, a fake investor seeking to purchase a big number of narcotics (or other illegal goods) could crowdfund a simulant company owned by a narcotics distributor. The investor/buyer would receive narcotics plus (worthless) equity. The issuer/narcotics distributor would receive funds electronically under the guise of a legitimate crowdfunding offering, which would be easier to integrate into the financial system than if the transaction were conducted in cash. There is also a possibility for terrorism funding in the crowdfunding system. The fake investors could crowdfund a sham company that intends to do charitable work abroad, which turned out to be terrorism funding.

The Indonesian Financial Services Authority (Otoritas Jasa Keuangan; OJK) with The Indonesian Financial Transaction Reports and Analysis Centre (Pusat Pelaporan dan Analisis Transaksi Keuangan; PPATK) and Indonesian FinTech Association has already held a Forum Group Discussion regarding the issues of money laundering and terrorism funding in financial technology. The proposed plan to be followed up is as follows (OJK, 2018a):

1. Preparation of identification and risk assessment of money laundering and terrorism financing which may arise from the Information Technology-Based Money Lending and Borrowing Services and Fund Service Providers through Technology-Based Share Offerings

2. Organization of risk-based guidelines for the implementation of Anti Money Laundering and Prevention of Terrorism Funding for industry players

3. Preparation of risk-based guidelines for monitoring compliance with the application of Anti Money Laundering and Prevention of Terrorism Funding

4. Incorporating FinTech players as one of the reporting parties that can make a report through the PPATK system 
5. Organizing some Capacity Building related to the Principles of Identifying Users, Aspects of Reporting Obligations, and the application of a Risk-Based Approach in Anti Money Laundering and Prevention of Terrorism Funding Program Arrangements

\subsubsection{Future Development}

- Competing or cooperating with Islamic Banks

Islamic crowdfunding can be either competitor or partner for Islamic banks. It could be a competitor because crowdfunding offers some benefits such as providing cheape access to capital and geographical boundaries are removed (Achsien and Purnamasari, 2016a). Thus, they help fill the gap left by the banks and will be the best alternative to start-ups and SMEs in developing their business.

Nevertheless, Islamic banks and Islamic Crowdfunding can also be a partner since they have the same goals to escalate the market share of Islamic banking and finance, specifically in Indonesia. This is proven by Ammana Fintek Syariah who has already partnered with BNI Syariah in terms of the utilization of Islamic banking products and services for Waqf. By the synergy, the collection of cash waqf by Ammana is expected to be more effective and efficient with the BNI Virtual Account product. This year, Ammana and BNI Syariah add some points regarding their partnership, namely Escrow Account and Lender Fund Account utilization to strengthen Ammana's services. Ammana has also conducted a partnership with Bank Muamalat Indonesia in the utilization of escrow account or Ammana fund holding at Bank Muamalat.

\section{- Cooperating with other Islamic Financial Institutions}

Besides partnering with the bank, Islamic crowdfunding could also cooperate with some other Islamic financial institutions. For instance, Ammana Fintek Syariah has collaborated with Baitul Mal wa Tamwil (BMT) which is an Islamic microfinance institution in Indonesia. The presence of BMT and Islamic cooperatives as curators for the performance of MSMEs (Micro, Small, and Medium Enterprises) that will be funded by lenders through Ammana. They are also taking a role as the agent of change for expanding the benefits of fintech technology to the entire community and helps standardize business governance of MSMEs players.

\section{- Stimulating Risky Sectors}

Due to risky reasons, banks mostly have large consideration for giving financing to nature-based businesses. To fill the gap, some crowdfunding platforms provide financing based on profit and loss sharing to the risky sector. In Indonesia, iGrow provides financing to agricultural entrepreneurship, and Growpal offers to finance the fishing industry.

\section{- Public awareness of Islamic Crowdfunding}

We believe that more education to the market about crowdfunding will solve the above-mentioned challenges and issues. Therefore, the government, Islamic crowdfunding industrial players and academics have to put some effort regarding the enhancement of public awareness of Islamic crowdfunding to make greater benefits in society.

\section{CONCLUSION}

The development and regulation of Islamic Crowdfunding in Indonesia are under the supervision of three institutions such as Bank Indonesia, Indonesian's Services Authority (OJK), and the National Islamic Board. BI sets the monetary and payment system (macro-level) while OJK regulates the financial institutions (micro-level). In 2018, the National Islamic Board (DSN-MUI) issued a fatwa about Islamic fintech "Financing Services Based on Information Technology Based on Sharia Principles". In the fatwa, DSN-MUI emphasizes the platforms may not contradict Sharia principles, like usury, gharar, maysir, tadlis, dharar, zhulm, and haram.

Islamic Crowdfunding is divided into four categories; donationbased, reward-based, asset-based, and equity-based crowdfunding. Islamic crowdfunding, especially equity based holds the promise of delivering accessible financial services to the unbanked SMEs in the country. SMEs have an important role in the Indonesian economy, but difficult to obtain financing from banks, thus they cannot access financial services. Islamic crowdfunding impacts the SMEs in regard to the ease of obtaining capital access, improving the welfare of SMEs, and creating growth for the national economy in the long-term.

\section{References}

Achsien, I., Purnamasari, D., 07 2016a. Islamic crowd-funding as the next financial innovation in islamic finance: Potential and anticipated regulation in indonesia. European Journal of Islamic Finance, 1-11. DOI: $10.13135 / 2421-2172 / 1771$

Achsien, I. H., Purnamasari, D. L., 2016b. Islamic Crowd-Funding as the Next Financial Innovation in Islamic Finance: Potential and Anticipated Regulation in Indonesia. Eutropean Journal of Islamic Finance 5, 1-11. URL: https : //doi.org/10.13135/2421-2172/1771

Agrawal, A., Catalini, C., Goldfarb, A., 2014. Some simple economics of crowdfunding. Innovation Policy and the Economy 14, 63-97. URL: https : //doi .org/10.1086/674021 DOI: $10.1086 / 674021$

Akbar, D. S. F., 2016. URL: https : //www. kemenkeu.go.id/media/4369/mendorongcrowdfunding-untuk-peningkatan-investasi-di-indonesia. pdf

Alonso, I. M., 2020. Crowdfunding Framework in Islamic Finance. Woosong University, Ch. 8.

Andaleeb, U., Mishra, D. A., 2016. Equity crowdfunding in shariah compliant nations: an outlook in the middle-east. Global Journal of Finance and Management 8 (1), 97-102.

URL: https : //www.ripublication.com/gjfm16/gjfmv8n1_09.pdf

Bock, A., Frydrych, D., Kinder, T., Koeck, B., 2014. Exploring entrepreneurial legitimacy in reward-based crowdfunding. Workingpaper.

Chironga, M., Dahl, J., Goland, T., Pinshaw, G., Sonnekus, M., 2012. Micro-, small and medium-sized enterprises in emerging markets: how banks can grasp a $\$ 350$ billion opportunity. Tech. rep.

Demirguc-Kunt, A., Klapper, L., Singer, D., Ansar, S., Hess, J., 2018. The Global Findex Database 2017: Measuring Financial Inclusion and the Fintech Revolution. Washington, DC: World Bank.

URL: https : //doi .org/10.1596/978-1-4648-1259-0 
Dewan Syariah Nasional, 2018. Layanan Pembiayaan Berbasis Teknologi Informasi Berdasarkan Prinsip Syariah.

URL:

https://drive.google.com/file/d/ 1qCu2X6MTIFnYqK22eMx7uFL53AXBT9Vo/view

Durkin, M., Laffey, D., Gandy, A., Cummins, D., Fearon, C., 2016. The sme bank relationship: Exploring the impact of crowdfunding at start-up. URL: https://www.ulster.ac.uk/__data/assets/pdf_file/ 0009/168417/crowdfunding.pdf

Estellés-Arolas, E., de Guevara, F. G.-L., 2012. Towards an integrated crowdsourcing definition. Journal of Information Science 38 (2), 189-200. URL: https://journals. sagepub.com/doi/abs/10.1177/ 0165551512437638

Financial Institutions Group, 2016. Women-owned SMEs in Indonesia: A Golden Opportunity for Local Financial Institutions.

Ibrahim, N., Verliyantina, 2012. The model of crowdfunding to support small and micro businesses in indonesia through a web-based platform. Procedia Economics and Finance 4, 390-397, international Conference on Small and Medium Enterprises Development with a Theme ?Innovation and Sustainability in SME Development? (ICSMED 2012).

URL: https://www.sciencedirect.com/science/article/pii/ S221256711200353X

DOI: https://doi.org/10.1016/S2212-5671(12)00353-X

IFBS (Ed.), 2017. Reinvigorating Momentum, Solidifying Resilience and Sustaining Growth. Proceeding of IFBS Summit 2017. Islamic FInancial Service Board, IFBS.

URL: https://www.islamicfinance.com/2017/07/ ifsb-view-islamic-crowdfunding/

Islamic Development Bank, 2015. Annual repert 1436h (2015). URL: https://www.isdb.org/sites/default/files/media/ documents /2018-12/IsDB-Annual\%20Report-1436H\%282015\%29. pdf

Jenik, I., Lyman, T., , Nava, A., 2017. Crowdfunding and financial inclusion. Tech. rep.

URL:

https://www.cgap.org/sites/default/files/
Working-Paper-Crowdfunding-and-Financial-InclusionMar-2017. pdf

Katadata.com, 2020. 10 fintech penyelenggara equity crowdfunding antre izin dari ojk.

URL:https://katadata.co.id/happyfajrian/finansial/ 5e9a4e60670ad/10-fintech-penyelenggara-equitycrowdfunding-antre-izin-dari-ojk

Kuppuswamy, V., Bayus, B. L., 2018. A review of crowdfunding research and findings. Edward Elgar Publishing Limited, Ch. 17.

URL: https://doi.org/10.4337/9781784718152

OJK, 2018a. Focus Group Discussion Peran Pelaku Fintech dalam pencegahan TPPU dan TPPT.

URL: https://www.ojk.go.id/apu-ppt/id/berita-dan-

kegiatan/info-terkini/Pages/Focus-Group-Discussion-PeranPelaku-Fintech-dalam-pencegahan-TPPU-dan-TPPT . aspx

Omar, Z., 12 2020. The impact of covid-19 on islamic banking in indonesia during the pandemic era. Journal of Entrepreneurship and Business 8, 1932.

URL: https://doi.org/10.17687/JEB. 0802.03

Retno Wati, C., Winarno, A., 04 2018. The performance of crowdfunding model as an alternative funding source for micro, small, and medium-scale businesses in various countries. KnE Social Sciences 3, 16. URL: https://doi.org/10.18502/kss.v3i3.1871

UMKM Indonesia, 2016. Potret UMKM Indonesia: Si Kecil yang Berperan Besar.

URL: https://www.ukmindonesia.id/baca-artikel/62

Wahjono, S., Marina, A., Widayat, 12 2015. Islamic Crowdfunding: Alternative Funding Solution.

Yusof, E., Kashoogie, J., Kamal, A., 01 2009. Islamic finance: Debt versus equity financing in the light of maqasid al-shari'ah. University Library of Munich, Germany, MPRA Paper.

Zheng, Y., Mckeever, B., Xu, L., 08 2016. Nonprofit communication and fundraising in china: Exploring the theory of situational support in an international context. International Journal of Communication 10, 4280-4303. 